mint a kéziratok kommentálásával, ötletek, kritikai gondolatok átadásával. Nagyon jó és könnyü volt együttdolgozni vele, nyitottsággal, bizalommal, kedvességgel, humorral, szelíd iróniával bánt minden munkatársával és tanítványaival. Az ELTE BTK más tanszékein is szívesen látott vendég volt, de szíve csücske az Elméleti nyelvészet szak maradt. A diákok lelkesedtek kurzusaiért. Ilyen volt a 2013 tavaszán tartott Száz év strukturalizmus (1913-2013) címü, melyben saját régebbi cikkeit is a diákokkal közös kritikai gondolkodás tárgyává tette, és a 2014/2015. tanévben tartott, Új fejlemények a nyelvtudományban címü kurzusa. Megvalósította, amiben hitt: azt, hogy a nyelvészet minden területét világszínvonalon, a nemzetközi nyelvészet integráns részeként kell müvelnünk és ennek megfelelően tanítanunk az egyetemeken. Szellemi örökségét megörizzük.

BÁNRÉTI ZOLTÁN

ELKH Nyelvtudományi Kutatóközpont

\title{
Búcsú Szabó Józseftől
}

(1940-2021)

Életének 81. évében, 2021. január 12-én elhunyt Szabó József nyugalmazott egyetemi tanár, az SZTE BTK Magyar Nyelvészeti Tanszékének volt oktatója és vezetője, a nyelvtudomány (MTA) doktora, a pozsonyi Comenius Egyetem egykori vendégprofeszszora. Halálával a magyar nyelvtudomány, különösen a dialektológia és a névtudományi kutatások nemzetközi rangú tudósa távozott körünkből.

Szabó József 1940. október 18-án született a Tolna megyei Nagykónyiban. Szülei földmüvelők voltak, s ő maga is gyermekkorától fogva mindig részt vállalt a különféle mezőgazdasági és ház körüli munkákban. Ezáltal igen alaposan megismerte a hagyományos paraszti gazdálkodást, a falusi emberek mindennapjait, gondolkodásmódját és néphagyományait. Az is nagyban hozzájárult szülőfaluja életének, hagyományainak megismeréséhez, hogy 18 éves koráig szülőfalujában élt. Nemcsak általános iskolai tanulmányait folytatta itt, de középiskolába is bejáró diákként járt a tamási Béri Balogh Ádám Gimnáziumba. Bizonyára ezek együttesen is szerepet játszottak abban, hogy rendkívül erős kötődése alakult ki szülőföldjéhez és annak lakóihoz: rokonaihoz, ismerőseihez. Ennek az erős érzelmi kapcsolatnak a későbbiekben meghatározó jelentősége volt pályájában, nyelvészeti kutatásainak tematikájában, hiszen írásainak igen nagy része, köztük több könyve is szülőfalujának nyelvjárását és népszokásait dolgozza fel.

1959-ben került a Szegedi Tudományegyetem Bölcsészettudományi Karára, magyar-orosz szakra. A magyar nyelvészet iránti érdeklődése az egyetemen alakult ki és mélyült el. Elsősorban Nyíri Antal nyelvtörténeti előadásait hallgatva jött rá arra, hogy szülőfaluja nyelvjárásának mennyi értékes jellemvonása van. Ezeket már harmadéves korában elkezdte diákköri dolgozatként gyüjteni, s szövegközlésként publikálni. De nemcsak a nyelvészeti témák iránt nyílt meg érdeklődése az egyetemen: már elsőévesként megismerhette Bálint Sándort. A vele való találkozás is igen meghatározó lett számára, 
egyúttal későbbi munkásságának egy másik igen fontos irányt adott. Számos olyan írása van ugyanis, melyek nem csupán nyelvjárási forrásmunkák, adatközlések, hanem a tárgyi és a szellemi néprajz számára is fontos adalékul szolgálnak.

Diplomája megszerzése után előbb tanárként dolgozott Szegeden, de közben már óraadóként tanított az egyetemen, illetve a tanárképző föiskolán is. Mindez folyamatos önképzésre ösztönözte. Ennek köszönhetően már 1966-ban megvédte bölcsészdoktori értekezését szülöfaluja dialektusáról (SzABÓ 1966). 1970-ben tanársegédi állást kapott a BTK Magyar Nyelvészeti Tanszékén, attól kezdve nyugdíjazásáig ott dolgozott: 1973 és 1979 között adjunktusként, 1979-től 1993-ig docensként, majd 1993-tól egyetemi tanárként. 1988 és 1990 között a tanszék vezetője is volt, 1992 és 1997 között pedig a pozsonyi Comenius Egyetem Magyar Nyelvi és Irodalmi Tanszékén is tanított vendégprofesszorként.

Kezdetben nyelvtörténeti, leíró hangtani és mondattani szemináriumokat vezetett, de a nyelvjárástan oktatása is a feladatkörébe tartozott. Ez utóbbi egész további pályáján oktatói tevékenységének centrumába tartozott. Kandidátusi értekezését is ebben a témában készítette el 1978-ban (SZABÓ 1983), de terjedelmes szövegkorpuszt is megjelentetett szülőfaluja nyelvi anyagából, majd elkészítette a nyelvjárás monografikus igényü feldolgozását is (SZABÓ 1986).

Mivel már középiskolás kora óta kedvelte a történelmet, ezen belül is különösen a település- és népiségtörténetet, az 1980-as évek közepétől egyre inkább a nyelvjárásszigetek problematikája felé fordult a figyelme. Több idevágó értekezése mellett ebben a témakörben készült el akadémiai doktori értekezése is (Magyarországi és jugoszláviai magyar nyelvjárásszigetek), melyet 1992-ben védett meg (SzABÓ 1990).

Kutatói aktivitása később is töretlen volt, ám vizsgálati horizontja fokozatosan szélesedett. A nyelvjárásszigetek vizsgálatán túl egyre jobban foglalkoztatták a névtani kutatások is, majd figyelme egyre inkább a népnyelv metaforikus kifejezései, valamint a török hódoltság nyelvünkben is továbbélő emlékei felé fordult. Idevágó kutatásait, melyek tanulmányokban is testet öltöttek, monográfiaszerüen is összefoglalta A népi szemléletmód tükröződése nyelvjárásaink szókészletében című könyvében (SZABÓ 2007), illetve A török hódoltság néprajzi és nyelvi maradványai földrajzi neveinkben címü kötetben (SZABÓ 2008).

Tagja volt számos tudós társaságnak is, köztük a Magyar Nyelvtudományi Társaságnak választmányi tagja is volt, de közremüködött a Nemzetközi Filológiai Társaság, valamint az Európai Nyelvatlasz Magyar Nemzeti Bizottságának munkájában is, sőt amikor 1998 októberében megalakult a német dialektológia nemzetközi társasága (Internationale Gesellschaft für Dialektologie des Deutschen), az ottani kollégák felkérése nyomán csatlakozott annak tagjaihoz is. Nyelvjáráskutatói munkájáért, valamint a földrajzi nevek gyüjtésében és közzétételében végzett tevékenységéért 1982-ben Csüry Bálint-emlékéremmel tüntették ki, 1999 és 2002 között pedig Széchenyi Professzori Ösztöndíjas volt.

Szülőföldjén sokan tudták s tudják róla, hogy foglalkozik a falu tájszólásával. Ezzel az indoklással kapta meg 1999-ben a Nagykónyi díszpolgára címet is. A magyar nyelvész pályaképek és önvallomások című sorozat 64. füzetében így beszélt erről: „Úgy látszik: többen is megérezhették, hogy az anyanyelvjárásom sajátságainak összegyüjtése és feldolgozása számomra kezdettől fogva nemcsak tudományos célú elemzés volt, hanem annál sokkal több is. A különböző nyelvjárási adatok közül egy-egy archaikus elemnek, szemléletes fordulatnak, nyelvi leleménynek az anyaggyüjtés során mint nyelvész mindig örülni tudtam, de mint embernek, lélekben nagykónyi lakosnak, egy-egy 
tájszó vagy szólás mindig jóval több volt egy adatnál: fölidézte s ma is fölidézi bennem gyermekkorom világát, s a mindennapi létért a természettel és társadalommal küszködő parasztember munkáját, erőfeszítéseit, nehézségeit, a paraszti létforma örömeit és gondjait egyaránt" (BOLLA 2002: 27).

Emlékét tisztelettel és szeretettel megőrizzük. Legyen neki könnyü a föld, az a föld, amelynek illatát a nagykónyi szántóföldeken, de baktói kiskertjét müvelve is annyira szerette. Nyugodjék békében!

\section{Hivatkozott irodalom}

Bolla KÁLMÁN szerk. 2002. Szabó József. Magyar nyelvész pályaképek és önvallomások 64. Budapest.

SZABÓ JÓzSEF 1966. Hangtani jelenségek Nagykónyi község nyelvjárásában. Doktori értekezés. Kézirat. Szeged.

SZABÓ JÓZSEF 1983. A mondatszerkesztés nyelvszociológiai vizsgálata a nagykónyi nyelvjárásban. Akadémiai Kiadó, Budapest.

SZABÓ JózSEF 1986. A nagykónyi nyelvjárás. Béri Balogh Ádám Múzeum. Szekszárd.

SZABÓ JÓZSEF 1990. Magyarországi és jugoszláviai magyar nyelvjárásszigetek. Csongrád Megyei Levéltár, Békéscsaba-Kecskemét-Szeged.

SZABÓ JózSEF 2007. A népi szemléletmód tükrözödése nyelvjárásaink szókészletében. Magyar Nyelvészeti Tanszék, Szeged.

SZABÓ JÓZSEF 2008. A török hódoltság néprajzi és nyelvi maradványai földrajzi neveinkben. Magyar Nyelvészeti Tanszék, Szeged.

FORGÁCS TAMÁS

Szegedi Tudományegyetem

\section{Csepregi Márta 70 éves*}

Múlik az idő, néha gyorsan, néha lassan. Amikor ráeszméltem, hogy immáron Márta is belelépett a nyolcadik tízesbe, kissé meglepődtem. Ennek pedig igen egyszerü oka van: valamiképpen rögzült bennem az a kép, amikor az MTA Nyelvtudományi Intézetének Finnugor Osztályán megjelent egy kellemes ifjú hölgy új kollégaként, aki Csepregi Mártaként és Hajdú Péter igazgatónk szegedi tanítványaként csatlakozott kis kutatói közösségünkhöz - vagyis ráeszméltem, hogy elszaladt az idő még Márta feje fölött is... Természetesen később is kapcsolatban voltam vele, de ennek az első alkalomnak a benyomásai mélyen elraktározódtak az emlékezetemben.

Szakmai berkekben nyilván igen jól ismert személyről van szó, sőt még a szakmán kívül is sokan ismerik Mártát, ennek ellenére talán nem árt egy röpke pillantást vetni az eddig megtett életútra.

Szinte karácsonyi gyerekként 1950. december 23-án látta meg a napvilágot Budapesten, majd az élet kisebb városok iskoláiba sodorta, végül a szegedi József Attila Tudományegyetemen kötött ki, ahol 1974-ben orosz-finnugor szakon szerzett diplomát.

\footnotetext{
* Elhangzott 2021. január 15-én, a Finnugor Szeminárium online konferenciájának megnyitóján.
} 